http://ejournal.upi.edu/index.php/jaz - e-mail: jurnal.zonasi@gmail.com dan jurnal_zonasi@upi.edu doi.org/10.17509/jaz.v3i2.25374

\title{
POLA PERGESERAN FUNGSI HUNIAN PADA BANGUNAN RUMAH TOKO kasus: transformasi bangunan di kawasan Pasar Baru-Bandung
}

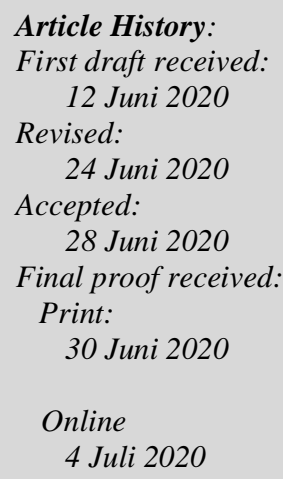

Jurnal Arsitektur ZONASI is indexed and listed in several databases:

SINTA 4 (Arjuna)

GARUDA (Garda Rujukan Digital)

Google Scholar

Dimensions

oneSearch

BASE

\section{Member:}

Crossref

RJI

APTARI

FJA (Forum Jurna Arsitektur)

IAI

AJPKM

\author{
Nurtati Soewarno \\ ${ }^{1}$ Institut Teknologi Nasional, Bandung \\ Jl. PH.H. Mustopha no. 23 Bandung, 40124 \\ Email: nurtati@itenas.ac.id
}

\begin{abstract}
Shop house is one of the building type in the city centre. This type emerged because of the additional trade activity. Both activities, household and trading, harmonically live side by side for a quiet long time. Problems emerged when the tradeing activity became more dominant and demands more space while the lot was limited. This condition tends to drive function and the physical of the building to transform. Nowadays its difficult to recognize the genuine form of a shop house, it has transform into a new shape that don't reflect the existence of a recidence function. At night, the city centre become quiet and dark, little or no existence of life, complete opposite with the daytime. By observation and typo-morfology approach this research will investigate the transformation on shop houses. Are the shop houses still occupied? Will the building transformation shift or even eliminate the occupancy function of the shop houses? The mass transformation on this area is feared to change the city centre into a busy trade area but no life at nights. The city centre as one of the most expencieve area is only properly to be used maximally both daytime and nightime, so the interference of the Local Government is expected to arrange the rules of changes. Transformation that occour is expected not to change the mixed area function: trade and residence, comfortable and worthy to be used day and night.
\end{abstract}

Keywords: shop house, building transformation, liveable area

\begin{abstract}
Abstrak: Rumah-toko adalah salah satu tipe bangunan hunian di kawasan pusat kota. Tipe ini lahir karena adanya tambahan aktifitas berdagang. Ke dua aktifitas ini, berhuni dan berdagang, harmonis berdampingan untuk kurun waktu yang cukup lama. Permasalahan timbul ketika aktifitas berdagang menjadi lebih dominan dan menuntut tambahan ruang sedangkan lahan terbatas. Kondisi ini cenderung mendorong terjadinya transformasi fungsi maupun fisik bangunan. Saat ini rumah-toko lama sudah sulit dikenali bentuk aslinya, telah bertransformasi dan melahirkan bentuk baru yang tidak mencerminkan keberadaan fungsi hunian. Di malam hari kawasan pusat kota menjadi sepi dan gelap, tidak ada kehidupan, hal yang berbeda dengan kondisi sepanjang siang hari. Dengan melakukan observasi dan pendekatan tipo-morfologi studi ini akan meneliti bentuk transformasi pada bangunan rumah-toko. Masihkan rumah-toko dihuni? Apakah transformasi bangunan menggeser atau bahkan menghilangkan fungsi hunian dari bangunan rumah-toko? Maraknya transformasi yang terjadi pada kawasan ini dikhawatirkan akan menghilangkan fungsi hunian pada kawasan perdagangan di pusat kota. Pusat kota sebagai kawasan termahal selayaknya digunakan secara maksimal siang dan malam hari oleh karenanya diperlukan campur tangan Pemerintah Daerah dalam mengatur perubahan. Diharapkan transformasi yang terjadi tidak merubah fungsi kawasan perdagangan sebagai kawasan campuran; hunian dan perdagangan yang nyaman dan layak digunakan sepanjang pagi hingga malam hari.
\end{abstract}

Kata Kunci: rumah-toko, transformasi bangunan, livable area

\section{Pendahuluan}

Perubahan atau transformasi adalah hal yang umum terjadi. Perubahan dapat diartikan sebagai sebuah peralihan, menjadi lebih baik atau sebaliknya. Perubahan di kota bersifat menyeluruh, meliputi perubahan 
sosial, ekonomi, budaya yang berdampak pada semua sektor. Bangunan merupakan salah satu yang terkena imbas dari sebuah perubahan. Perubahan pada fisik bangunan cenderung lebih mudah dikenali di kawasan perdagangan di pusat kota yang perkembangannya sangat pesat.

Kawasan pusat kota yang dimaksud adalah kawasan kota lama, yaitu kawasan yang pertama dibangun dan merupakan embrio dari sebuah kota (Rossi, 1982). Untuk kota-kota di Jawa kawasan ini ditandai dengan keberadaan alun-alun yang dikelilingi oleh bangunan-bangunan perkantoran, mesjid dan tidak jauh dari lokasi tersebut terdapat sebuah pasar. Pasar ini merupakan pasar tradisional tertua yang merupakan pusat dari sebuah kampung pribumi (Soewarno, 2013). Sejalan dengan perkembangan kota kawasan ini berkembang menjadi kawasan perdagangan dengan pasar sebagai pusatnya.

Kawasan perdagangan pertama di kota Bandung adalah kawasan Pasar Baru. Kawasan ini dapat dikenali dari deretan bangunan rumah-toko di ke dua sisi jalan dengan Pasar Baru sebagai pusatnya. Dengan melakukan observasi ke lapangan diperoleh data keberadaan rumah-toko lama dengan berbagai gaya arsitektur; tradisional, China dan Eropa, beberapa diantaranya merupakan bangunan cagar budaya. Pola grid yang diterapkan sejak awal masih terjaga tetapi tidak demikian dengan susunan bangunan pada setiap bloknya. Bangunan rumah-toko yang semula berderet di sisi luar blok saat ini sebagian besar berekspansi ke arah dalam sehingga mendesak kampung sebagai lingkungan hunian di blok dalam.

Makalah ini bertujuan untuk mempelajari bentuk transformasi pada bangunan rumah-toko. Transformasi bangunan terutama dilihat dari sisi tipologi-geometri sebagaimana yang dikemukakan oleh (Alexander, 1987), yaitu perubahan bentuk geometri dengan komponen pembentuk dan fungsi ruang yang kurang lebih serupa. Sementara itu dalam kategori lainnya juga terdapat transformasi gramatika yang menggeser, memutar dan mencerminkan objek serta transformasi yang lebih bersifat mendistorsi.

Adakah kaitan antara transformasi bangunan dengan hilangnya fungsi hunian? Dengan maraknya ekspansi bangunan rumah-toko dikhawatirkan blok dalam sebagai lingkungan hunian akan terdesak atau bahkan punah. Dengan mengadakan observasi dan pendekatan tipo-morfologi diambil beberapa kasus untuk dipelajari bentuk transformasi dan bagaimana transformasi berpengaruh terhadap keberadaan fungsi hunian. Diperlukan campur tangan Pemerintah Daerah untuk mengatur perubahan sehingga kawasan pusat kota sebagai kawasan termahal di kota diharapkan dapat digunakan secara maksimal untuk kegiatan perdagangan serta hunian dan tidak hanya menjadi kawasan yang sibuk sepanjang pagi hingga sore hari saja.

\section{Metode Penelitian}

Typo morphological modification is introduced, to connect architectural languages between past and present, to establish the relationship between architectural typology and urban morphology, and to keep urban identity and character (Moneo, 1978).

Kota adalah sebuah objek arsitektur yang merupakan hasil kreasi manusia yang tidak pernah berhenti. Pembangunan di kota bersifat sementara dan dinamis (Rossi, 1982). Oleh karena itu untuk mempelajari sebuah kota tidak bisa hanya dilihat pada suatu saat, masa kini tetapi harus dilihat keadaan kota tersebut di masa lampau melalui sejarahnya. Untuk itu metode tipo-morfologi dinilai cocok diterapkan untuk melihat sebuah obyek berkaitan antara masa lalu dan masa kini,

Dengan berjalannya waktu terjadi perubahan atau transformasi yang dapat berupa alih rupa atau perubahan menjadi bentuk yang berbeda namun mempunyai nilai-nilai yang sama, memiliki arti atau ungkapan yang sama menyangkut struktur permukaan dan fungsi (Ching, 1979). Transformasi merupakan suatu akhir dari proses peralihan secara penuh dari suatu bentuk menjadi bentuk baru melalui proses yang dijalani secara bertahap dengan dipengaruhi oleh ruang dan waktu.

Kurang lebih senada, (Anthony, 1992) mengemukakan transformasi sebagai sebuah proses perubahan secara berangsur-angsur sehingga sampai pada tahap puncak. Perubahan dilakukan dengan cara memberi respon terhadap pengaruh unsur eksternal dan internal yang mengarahkan perubahan dari bentuk yang sudah dikenal sebelumnya melalui proses menggandakan secara berulang atau melipat gandakan objek.

\section{Rumah-toko di Kawasan Pasar Baru}

\subsection{Sejarah kawasan Pasar Baru}

Pasar Baru bukanlah pasar pertama di Bandung. Pasar ini didirikan untuk menampung para pedagang dari Pasar pertama yang habis terbakar pada waktu terjadi pemberontakan Munada pada tahun 1842 (Kunto, 1984) . Pasar lama terletak tidak jauh dari lokasi kantor Kabupaten sedangkan Pasar Baru ditempatkan di sisi barat kawasan Pecinan yaitu di Pasar Baroeweg (sekarang jl Oto Iskandardinata). 
Pasar Baru didirikan di lingkungan hunian masyarakat pribumi Sunda. Penempatan pasar ini membawa dampak terhadap bangunan-bangunan di sekitarnya. Rumah-rumah mengalami perubahan fungsi dan bentuk, dimulai dengan menambahkan fungsi warung di bagian muka dengan teritisan untuk melindungi pembeli dari sengatan matahari dan hujan, bentuk ini merupakan cikal bakal rumah-toko di kawasan Pasar Baru.
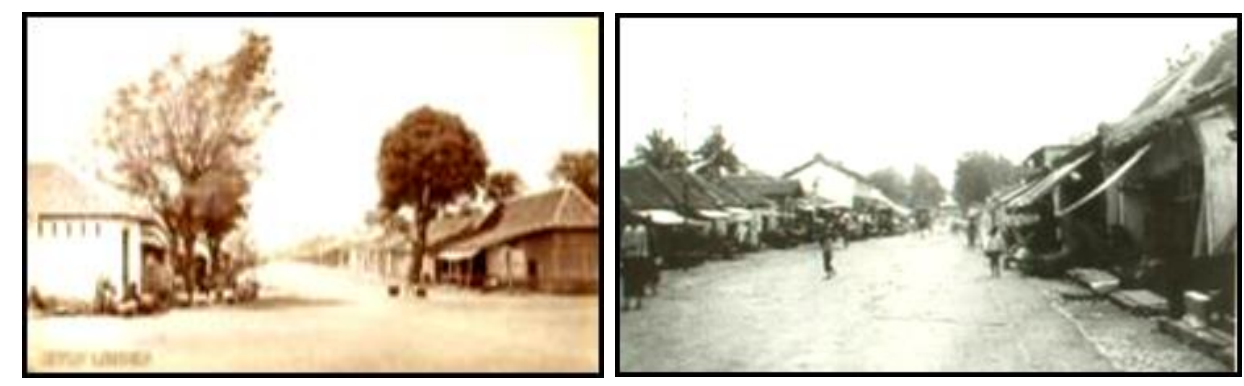

Gambar 1: Suasana Pasar Baru pada tahun 1800 an dan 1900 an; cikal bakal rumah-toko Sumber: KITLV-Leiden, Voskuil 1996

\subsection{Status kapling tanah}

Melihat kepada sejarah perkembangan kota, hampir semua kota-kota di Indonesia dibangun pada masa pemerintah Kolonial Belanda. Titik pusat kota (alun-alun) dibangun di kawasan yang telah ada penghuninya, yaitu dekat dengan kampung-kampung penduduk pribumi (Siregar, 1990).

Di kota Bandung kawasan pusat kota dibentuk dengan menerapkan pola semi grid pada kampung masyarakat Sunda. Kondisi ini membagi kampung dan lahan-lahan perkebunan menjadi blok-blok meskipun tidak sama luasnya tetapi setiap blok di kelilingi oleh empat buah jalan. Seiring dengan perkembangan kota sisi-sisi blok secara perlahan diisi oleh bangunan-bangunan yang berorientasi ke jalan di mukanya (gambar 2).

Bangunan di blok luar terlihat berjejer rapih mengelilingi blok. Kapling-kapling tanah di blok luar kemudian menjadi milik Pemerintah Kolonial atau bangsa asing lainnya (Kunto, 1984). Kapling tanah ini dikenal sebagai tanah barat dan setelah kemerdekaan Republik Indonesia menjadi tanah formal. Berbeda halnya dengan kapling tanah di blok dalam yang merupakan tanah adat yang dikuasai pribumi secara bergenerasi dan menjadi tanah informal karena tidak terdaftar di pemerintah (Ismet Belgawan, 2001). Blok dalam merupakan hunian yang saat ini dikenal sebagai Kampung Kota.

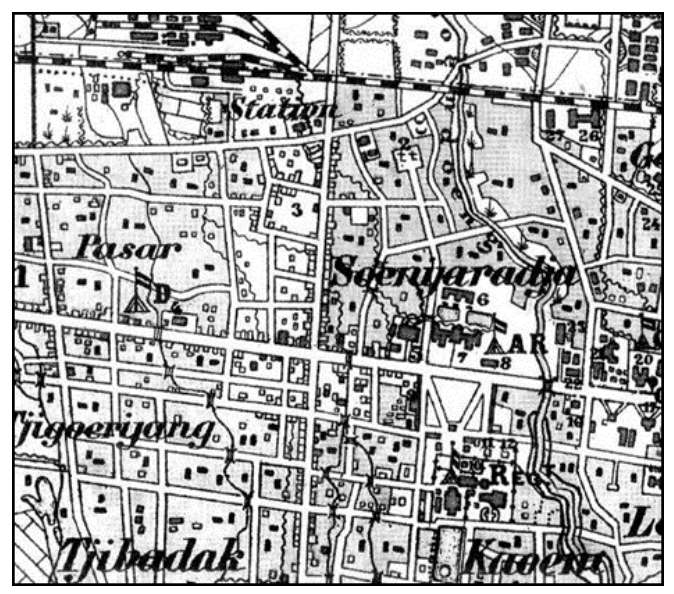

Gambar 2: Kondisi blok pada tahun 1882

Sumber: KITLV-Leiden, Voskuil 1996

Adapun bangunan yang didirikan pada blok luar adalah bangunan rumah-toko yang keberadaannya dirasakan tepat sebagai tempat untuk berhuni dan berdagang. Berbeda halnya dengan di blok dalam, semula blok dalam adalah kebun-kebun yang batas kepemilikannya berupa batas alam, seperti aliran air, tanggul, deretan pohon dan sebagainya. Bangunan-bangunannya didirikan sesuai dengan kebutuhan saat itu dan berorientasi ke kebunnya masing-masing. Bentuk-bentuk ini menjadi awal ketidak beraturan tata letak massa bangunan di blok dalam (Soewarno, 2013). 
Perkembangan kota dan pembangunan yang tidak merata mendorong terjadinya urbanisasi. Para pendatang memilih kampung kota sebagai tempat tinggal, harga sewa lebih murah, lokasi di pusat kota dan akses pencapaian mudah meskipun rumah dan fasilitas sangat sederhana. Oleh karenanya kebun-kebun berganti dengan bangunan-bangunan baru dan karena status tanahnya, informal, maka tidak ada aturan yang diterapkan dalam pembangunannya. Hal ini menjadikan tatanan massa bangunan di sisi blok dan di blok dalam terihat kontras, baik dari tatanan massa, gaya arsitektur maupun material yang digunakan.

\subsection{Tipo-Morfologi bangunan rumah-toko}

Pada bulan Februari 1906 Bandung ditetapkan sebagai gemeente atau kota praja. Langkah pertama Pemerintah kota Bandung menetapkan peraturan baru, salah satunya adalah bangunan yang menghadap ke jalan utama kota haruslah bangunan tembok atau bangunan permanen (Kunto, 1984). Hal ini mendorong perubahan pada deretan bangunan-bangunan di sisi jalan utama, dari bangunan semi permanen menjadi bangunan permanen satu sampai dua lantai dengan berbagai gaya arsitektur (gambar 3). Tipologi bangunan rumah-toko dapat dikenali dari sisa-sisa bangunan yang hingga kini masih bertahan (tabel 1).

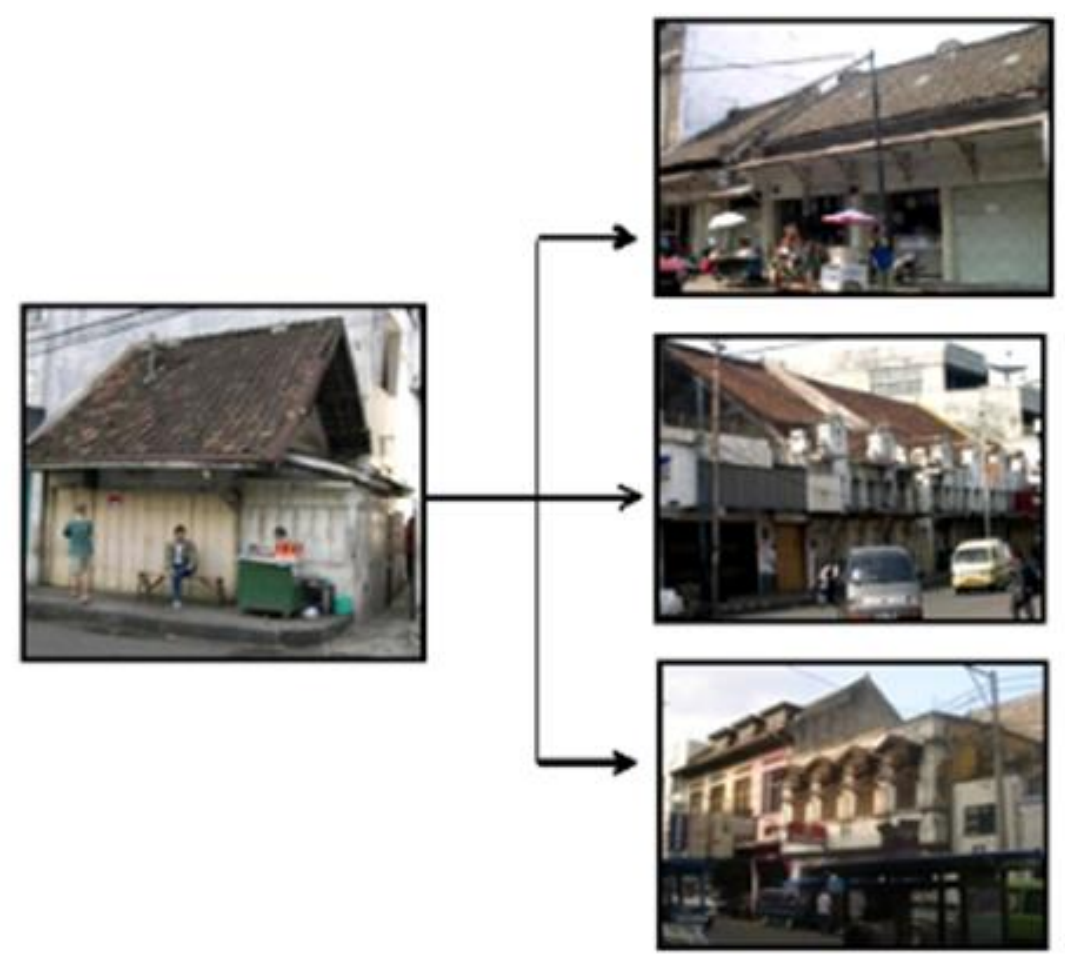

Gambar 3: Perkembangan rumah-toko semi permanen menjadi permanen Sumber: survey, 2012

Tabel 1: Tipologi awal bangunan rumah-toko

\begin{tabular}{|l|l|l|}
\hline $\begin{array}{l}\text { Rumah-toko } \\
\text { tradisional Sunda }\end{array}$ & $\begin{array}{l}\text { - Menggunakan material } \\
\text { tidak permanen; kayu, bilik } \\
\text { dan bambu } \\
\text { Menggunakan atap Julang } \\
\text { ngapak sebagai atap } \\
\text { tradisional bangunan Sunda }\end{array}$ \\
\hline $\begin{array}{l}\text { Rumah-toko } \\
\text { Modern }\end{array}$ & $\begin{array}{l}\text { Menggunakan material } \\
\text { permanen } \\
\text { Ketinggian langit-langit } \\
\text { mengikuti gaya rumah } \\
\text { Belanda yang beradaptasi } \\
\text { terhadap iklim tropis } \\
\text { Menerapkan gaya arsitektur } \\
\text { yang popular pada saat itu }\end{array}$ \\
\hline
\end{tabular}



Volume 3 - Nomor 2 - Juni 2020

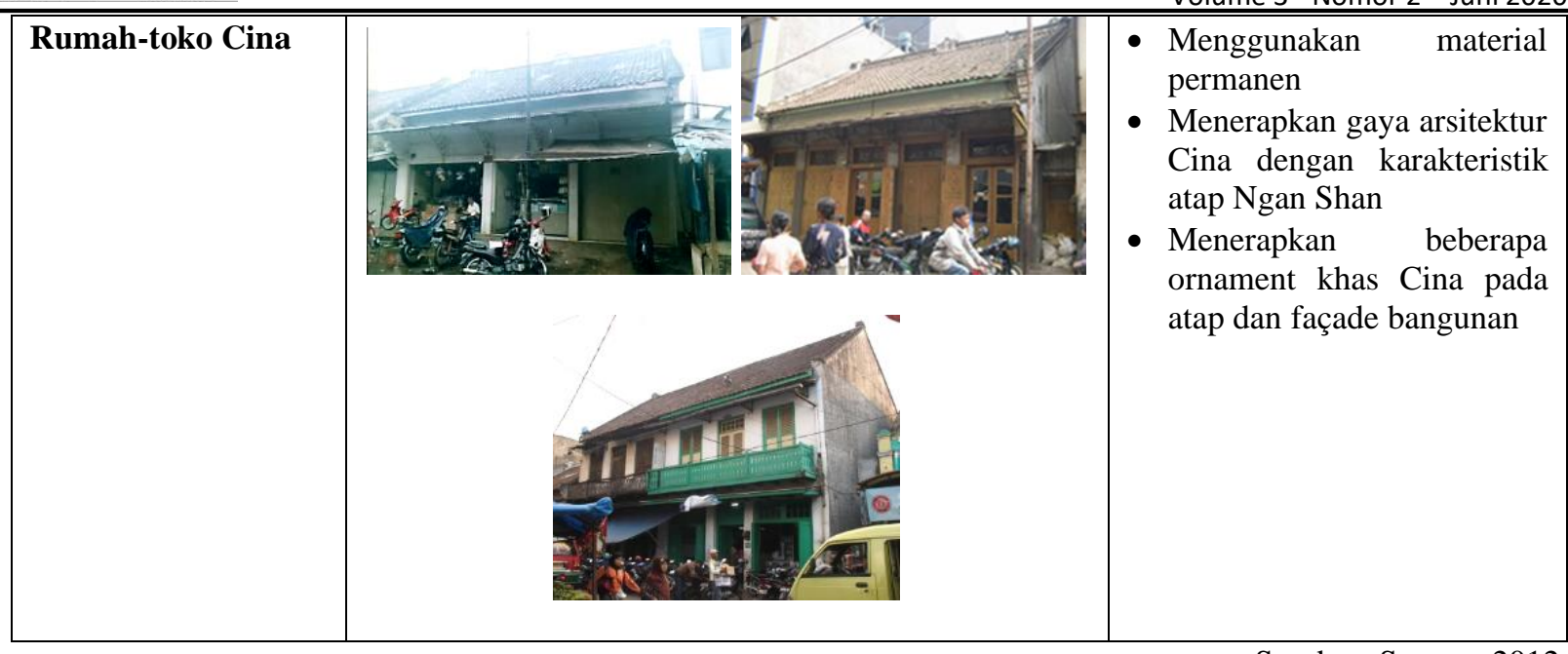

Sumber: Survey, 2012.

Dominasi masyarakat Cina menguasai perekonomian kota terlihat dari dominasi bangunan rumah-toko dengan arsitektur Cina yang dapat dikenali dari bentuk atap, ornament pada façade bangunan (gambar 4). Masyarakat Cina dipercaya dapat menghidupkan perekonomian kota melalui aktifitas berdagang yang berpengaruh terhadap perkembangan kota (Tjiook, 2018). Oleh karenanya lokasi Pecinan di setiap kota selalu berada di sekitar kawasan pasar, stasiun dan disekitar jalan raya utama pada setiap kota (Sugiri, 2012).
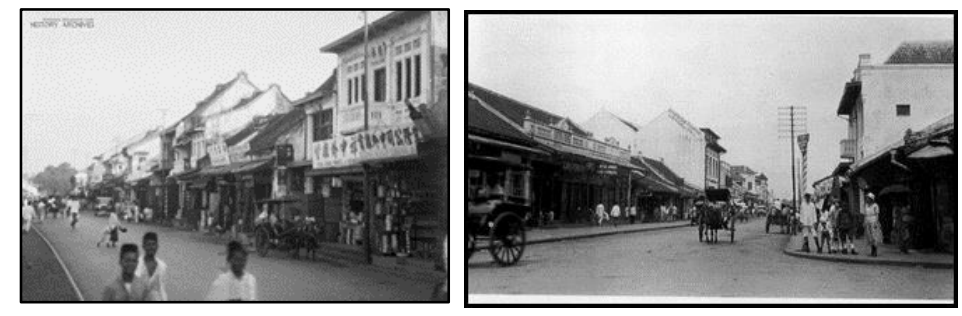

Gambar 4: Rumah-toko dengan gaya arsitektur Cina mendominasi kawasan perdagangan Sumber: https://didasadariksa.wordpress.com/2010/11/02/sejarah-masyarakat-tionghoa-di-bandung/ dan Voskuil, 1996

Dengan membaca beberapa makalah mengenai Pecinan di beberapa kota, seperti di Kendari (Santi, 2011), Semarang (Sudarwani, 2010), Banda Aceh (Mandasari, Fenny; Nurini, 2013) ditemukan kesamaan pola Pecinan di beberapa kota dan juga tipe bangunan rumah-toko Cina, seperti halnya di pecinan Bandung yang berlokasi di sekitar Pasar Baru (Sugiri, 2012). Pada saat itu sistem perpajakan di masa lalu yang menghitung pajak hanya berdasarkan lebar bangunan menghasilkan bangunan-bangunan mempunyai lebar sama, perbedaan terletak pada ukuran panjang bangunan ke arah belakang, ke kampung pribumi. Oleh karenanya dapat dikatakan terdapat 2 tipe bangunan rumah-toko berdasarkan luas kapling tanahnya (gambar 5), kapling kecil dan kapling besar.

Bangunan pada ke dua tipe luas kapling memiliki karakter gaya Arsitektur Cina seperti diungkapkan oleh (Kohl, 1984) : menerapkan bentuk atap Ngan shan, dengan inner court sebagai core untuk sirkulasi udara di dalam bangunan dan kaya akan ornament Cina pada atap dan façade bangunannya. Meskipun ke duanya berada pada kapling yang berbeda tetapi ke dua tipe ini mempunyai façade yang similar.

Perbedaan ke dua tipe ini terlihat dari jumlah suhunan yang dimiliki, bangunan yang terletak pada kapling kecil hanya memiliki satu suhunan (satu atap) sedangkan bangunan pada kapling besar memiliki lebih dari satu suhunan, tergantung kepada kondisi ekonomi pemiliknya. Sedangkan inner court pada bangunan di kapling kecil hanya memungkinkan terletak di bagian belakang sedangkan pada kapling besar dapat diterapkan di tengah, berupa beranda atau taman dan di belakang bersatu dengan area service. Pada perkembangan selanjutnya ke dua tipe ini akan menghasilkan tipe transformasi yang berbeda bergantung kepada dimensi kapling tanahnya (Soewarno, Hidjaz, \& Virdianti, 2018). 


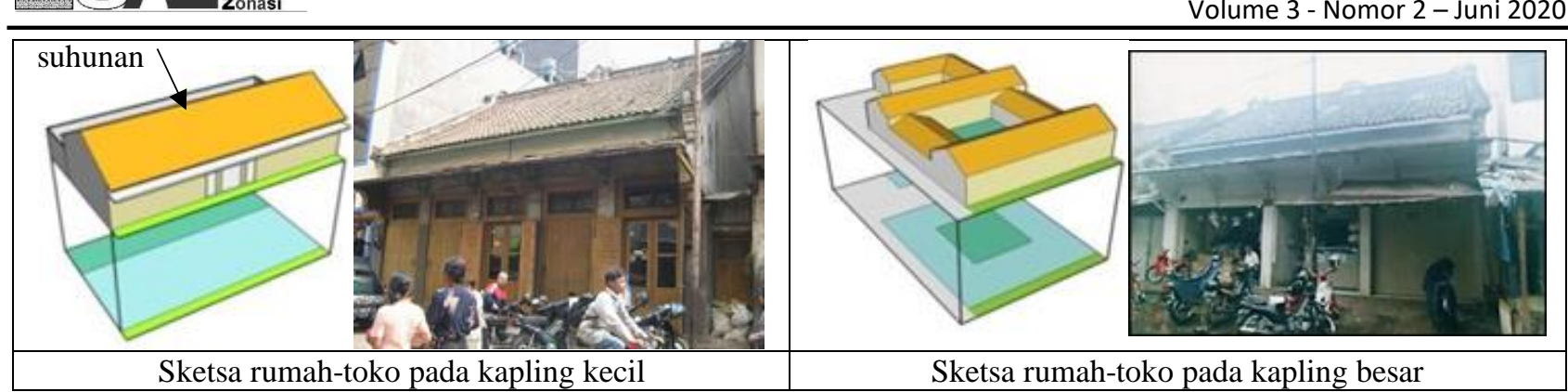

Gambar 5: Tipe bangunan rumah-toko berdasarkan luas kapling

Sumber: analisis, 2013

\subsection{Transformasi bangunan rumah-toko}

Luasnya kawasan Pasar Baru dan terbatasnya waktu penelitian, maka kasus studi di batasi hanya pada blok-blok yang berdekatan dengan Pasar Baru. Pembatasan ini berdasarkan efek yang ditimbulkan dari keberadaan Pasar Baru terhadap perkembangan bangunan pada sebuah blok, semakin jauh lokasi dari Pasar Baru semakin sedikit perkembangannya, terutama pada bangunan di blok dalam. Oleh karenanya studi dibatasi hanya pada blok-blok seperti pada gambar 6 yang terdiri dari 15 blok dengan jumlah bangunan 1.099 buah.

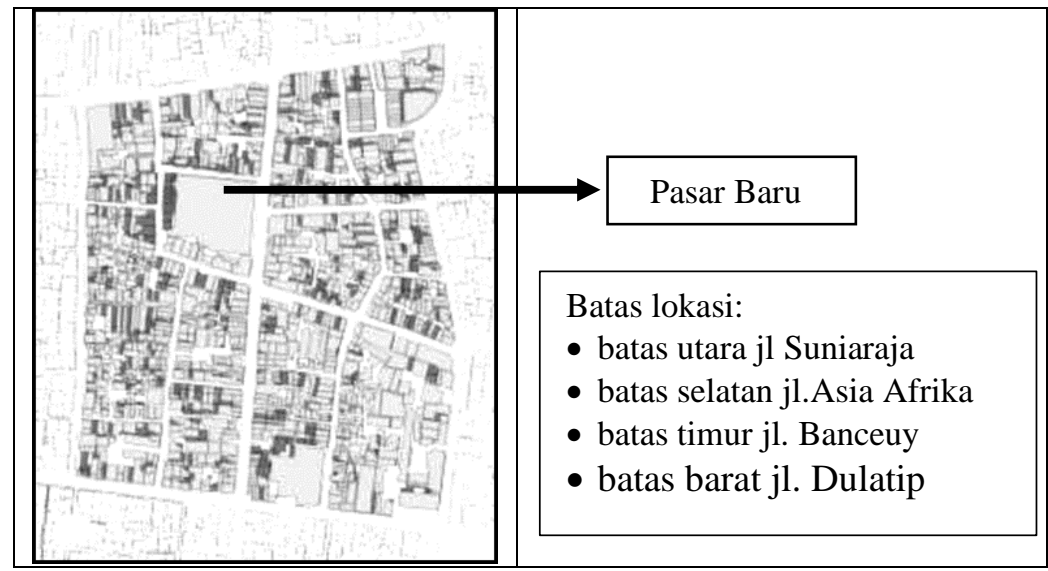

Gambar 6: Peta batasan lokasi penilitian

Sumber: diolah dari Google Earth, 2012

Pusat kota adalah kawasan yang sarat akan berbagai permasalahan, salah satu masalah yang sering terjadi adalah perebutan kapling tanah. Kapling tanah merupakan salah satu harta warisan yang dapat diturunkan bergenerasi dan dapat dibagi diantara penerima warisan ataupun diperjual belikan, demikian pula dengan bangunan. Melihat kondisi bangunan rumah-toko saat ini sudah sulit ditemukan rumah-toko yang masih utuh, dimiliki oleh satu orang pemilik, sebagian besar sudah terbagi-bagi menjadi unit yang lebih kecilkecil. Perbedaan kepemilikan dapat dibedakan dari perbedaan warna, desain pintu masuk meskipun masih merupakan sebuah unit bangunan (gambar 7).

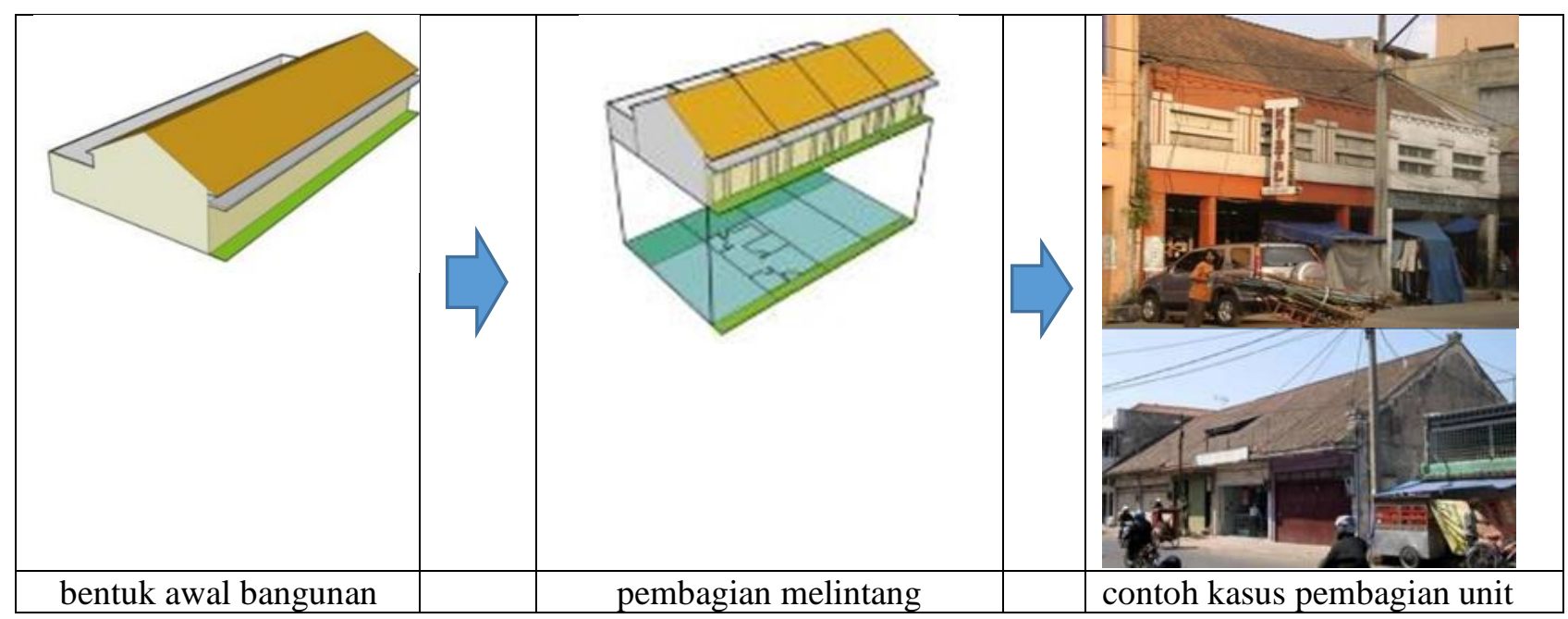

Gambar 7: Pembagian pada sebuah bangunan rumah-toko

Sumber: analisis, 2013 
Perbedaan kepemilikan ini merupakan cerminan dari pembagian warisan dan karena berdagang merupakan sebuah tradisi yang dapat diwariskan, maka pembagian kapling dilakukan secara melintang sehingga setiap unit hasil pembagian masih mempunyai akses ke muka untuk kemudahan pencapaian. Oleh karenanya jumlahnya pembagian dapat bervariasi tergantung jumlah anak laki-laki yang dimiliki (Soewarno, 2014).

Masalah akan timbul bila tuntutan aktifitas berdagang menjadi lebih dominan sehingga diperlukan tambahan ruang sedangkan kapling terbatas. Salah satu solusi adalah perkembangan ke arah vertikal dengan menambah lantai bangunan. Transformasi bentuk ini adalah yang paling banyak terlihat, kemajuan teknologi dan perkembangan material memungkinkan untuk hal ini dan didukung oleh peraturan yang mengizinkan saat itu (tahun 2012) jumlah lantai bangunan hingga 4 lantai (Soewarno, 2013). Perkembangan terjadi secara parsial tetapi secara perlahan tapi pasti akan menghilangkan bentuk asli dari rumah-toko Cina dan akan menghasilkan ke aneka ragaman bentuk serta gaya arsitektur bangunan rumah-toko di kawasan perdagangan (gambar 8).

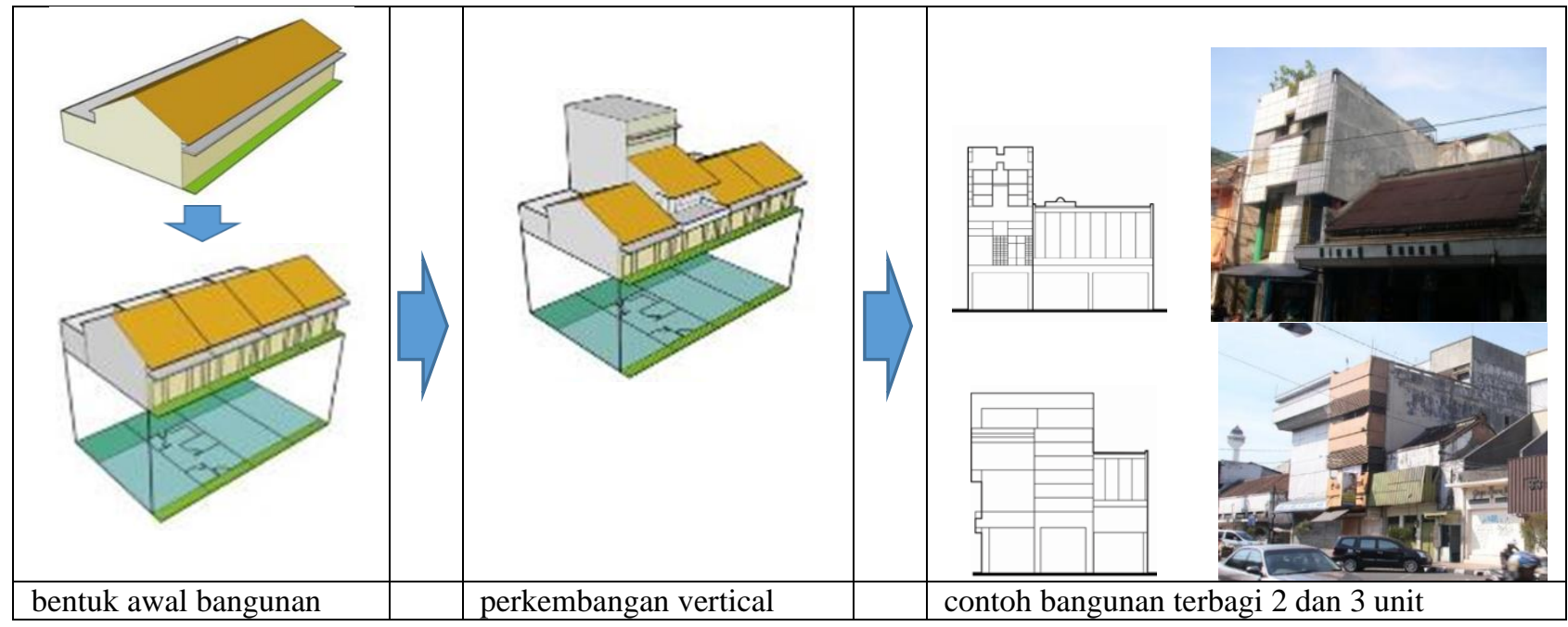

Gambar 8: Transformasi pada kapling kecil

Sumber: analisis, 2013

Kondisi serupa terjadi pula pada bangunan rumah-toko yang terletak pada kapling besar. Perkembangan dari pembagian warisan akan menghasilkan bentuk-bentuk yang lebih dinamis dan cenderung lebih tidak beraturan. Keberhasilan usaha menuntut ruang aktivitas yang lebih dan terbatasnya lahan mendorong transformasi ke arah vertikal. Tipe ini dapat dikenali dari bangunan rumah-toko yang pipih memanjang ke arah belakang, ke arah kampung kota (gambar 9).

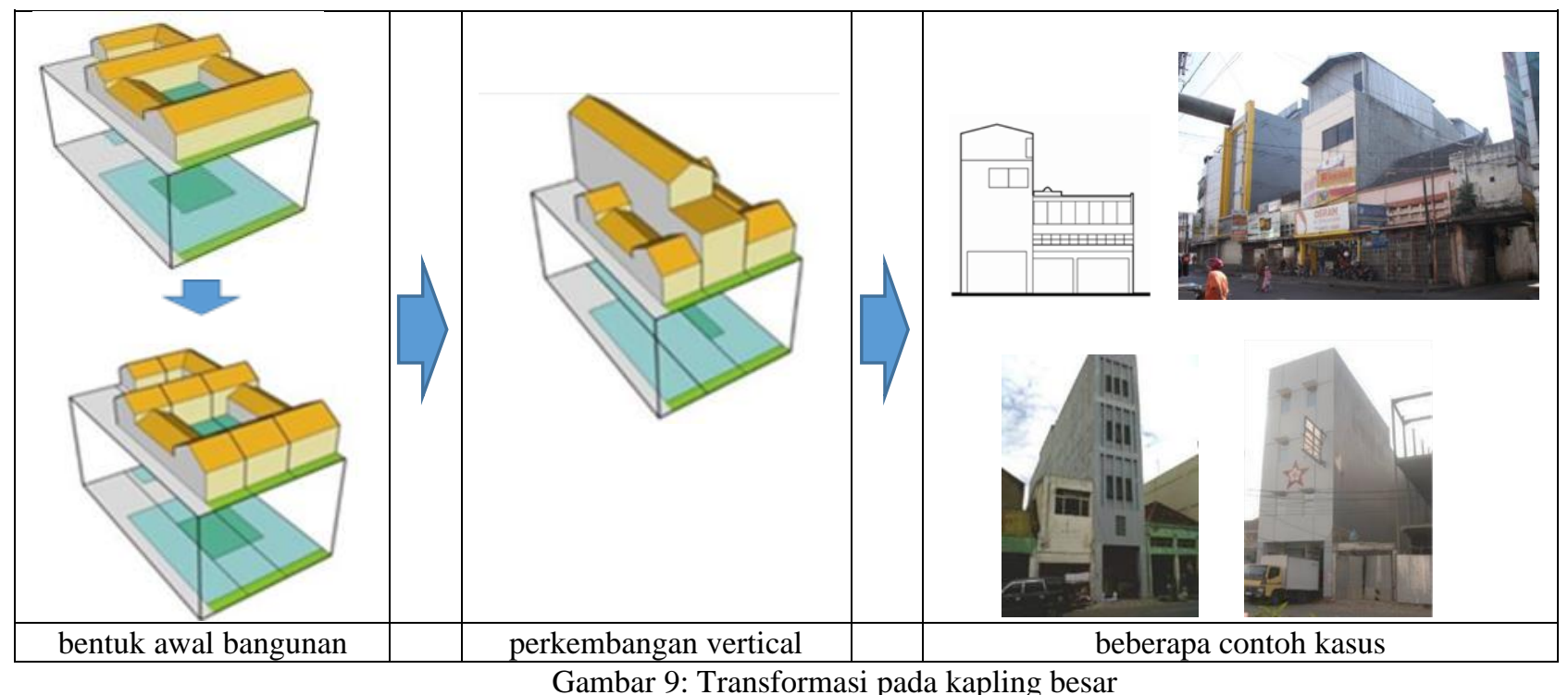

\subsection{Pola pergeseran fungsi hunian}

Sumber: analisis, 2013

Rumah-toko adalah bangunan dengan fungsi ganda: hunian dan perdagangan. Pola awal bangunan rumah-toko adalah fungsi perdagangan berada di area publik sedangkan fungsi hunian berada di area privat. 
Untuk rumah-toko satu lantai fungsi toko berada di depan dan hunian di belakang sedangkan untuk rumahtoko berlantai fungsi toko berada di lantai bawah dan hunian berada di lantai atas (gambar 10).

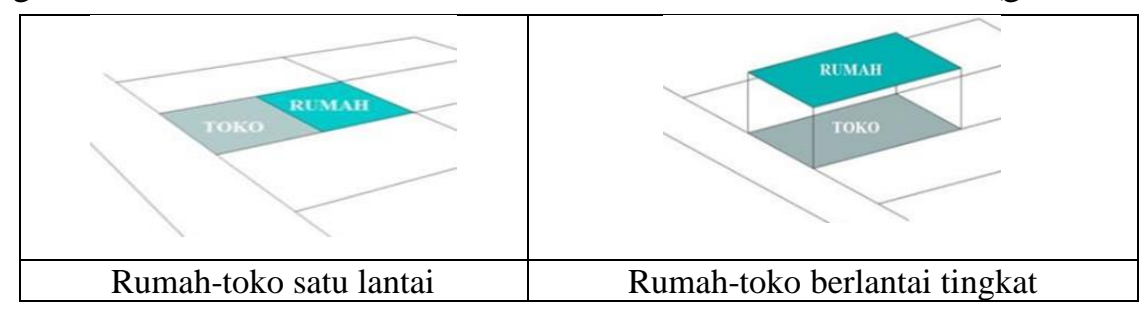

Gambar 10: Pola awal fungsi rumah-toko

Sumber: analisis, 2013

Sejalan dengan berlalunya waktu perkembangan teknologi dan ekonomi di kota Bandung melaju dengan pesat di segala sektor: teknologi, budaya dan ekonomi. Di kawasan perdagangan hal ini tercermin dari perkembangan bangunan rumah-toko sebagai wadah aktifitas berdagang. Rumah-toko mengalami perubahan, dimulai dengan meningkatnya jenis usaha dagang yang berdampak terhadap perubahan fisik bangunannya. Salah satu contoh adalah sebuah toko yang awalnya hanya menjual kancing dari bahan plastik, dengan meningkatnya teknologi jenis kancing menjadi bervariasi model dan materialnya. Saat ini toko tersebut tidak hanya menjual kancing tetapi aneka macam asesoris untuk keperluan garment, seperti: benang dengan aneka ukuran, ritsleting dengan aneka ukuran dan bahan, aneka model kancing untuk kemeja, celana dan jacket. (me)

Perkembangan jenis usaha meningkatkan kebutuhan ruang untuk aktifitas berdagang terutama untuk area jual, gudang penyimpanan karena stock barang lebih beragam. Selain itu meningkatnya teknologi memungkinkan pemasaran melalui media komunikasi secara on line, sehingga pembeli tidak terbatas mereka yang tinggal di Bandung saja. Pemasaran yang semula dipegang hanya oleh anggota keluarga kini melibatkan pihak lain sehingga diperlukan ruang kantor dan ruang-ruang pelengkap seperti ruang makan karyawan, mushola dan toilet.

Terbatasnya lahan dan desakan kebutuhan ruang untuk berdagang menggeser fungsi hunian, gejala ini terjadi baik pada rumah-toko satu lantai maupun rumah-toko berlantai. Dominasi ruang digunakan untuk area toko, gudang dan hanya sedikit ruang tersisa untuk pemiliki toko dan digunakan sebagai pantry. Kondisi ini tidak memungkinkan bagi pemilik toko untuk tetap tinggal sehingga rumah-toko hanya digunakan untuk kegiatan berdagang di pagi hingga sore hari dan dibiarkan kosong di malam hari.

Tabel 2: pola tergesernya fungsi hunian

\begin{tabular}{|l|l|l|}
\hline \multicolumn{2}{|c|}{ Pola awal } & \multicolumn{1}{|c|}{ Keterangan } \\
\hline 1. Rumah-toko satu lantai & $\begin{array}{l}\text { Fungsi hunian terdesak ke } \\
\text { belakang berupa pantry. }\end{array}$ \\
\hline 2. Rumah-toko berlantai & $\begin{array}{l}\text { Lantai dasar digunakan untuk } \\
\text { toko, gudang dan ruang } \\
\text { istirahat karyawan. } \\
\text { Lantai atas untuk gudang dan } \\
\text { pantry }\end{array}$ \\
\hline
\end{tabular}

Sumber: analisis 2013

Tingginya persaingan di kawasan perdagangan di pusat kota menyebabkan mereka yang tidak kuat berkompetensi memilih meninggalkan kawasan pusat kota dan mencari keuntungan di kawasan perdagangan lain yang kini tersebar di beberapa lokasi di kota Bandung. Bangunan yang ditinggalkan menjadi kesempatan bagi mereka yang kuat berkompetensi untuk memperluas bangunan. Penawaran pertama diajukan kepada pemilik toko yang berada disampingnya yang masih merupakan keluarga. Pembelian dapat terjadi secara keseluruhan ataupun parsial, bagian belakang saja atau bagian depan tergantung kesepakatan. Hal ini dapat dilihat dari perbedaan bentuk fisik bangunan.

Tipe transformasi ini umumnya tidak dapat mengembalikan fungsi hunian karena penambahan ruang tidak cukup untuk menampung dua fungsi seperti pola awal rumah-toko, hunian dan perdagangan. Transformasi tipe ini dapat dikenali dari bentuk-bentuk penggabungan rumah-toko ke arah samping, kiri, kanan atau kiri dan kanan tergantung kepada keberuntungan mendapatkan unit yang berada di sampingnya dan 
perbedaan fisik, material dan warna bangunan. Tipe ini menghasilkan keberagaman dan ketidak beraturan bentuk rumah-toko (gambar 11).

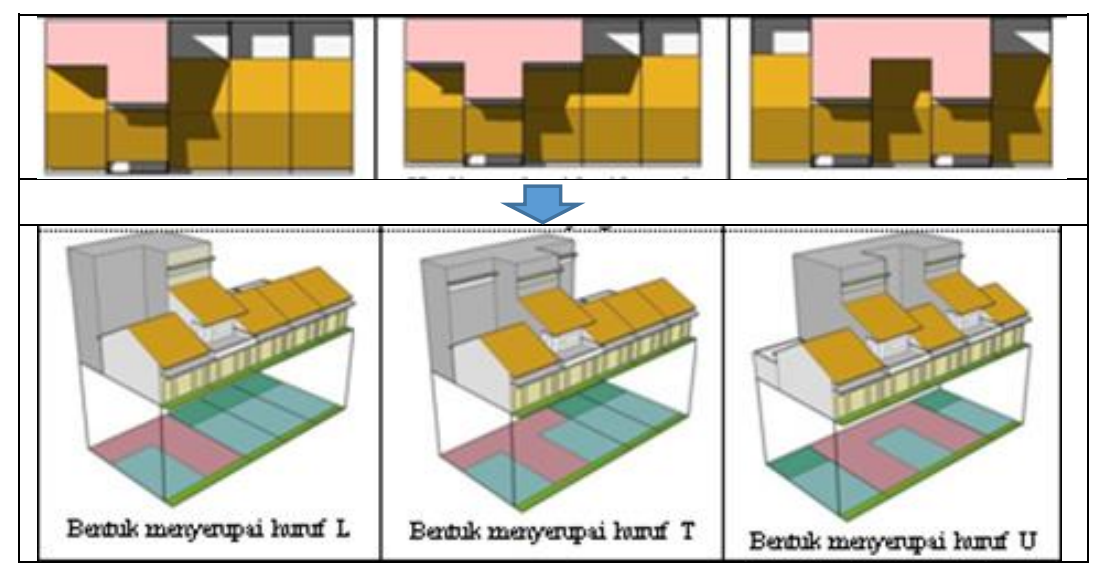

Gambar 11: Transformasi mengikuti perkembangan dimensi kapling

Sumber: analisis, 2013

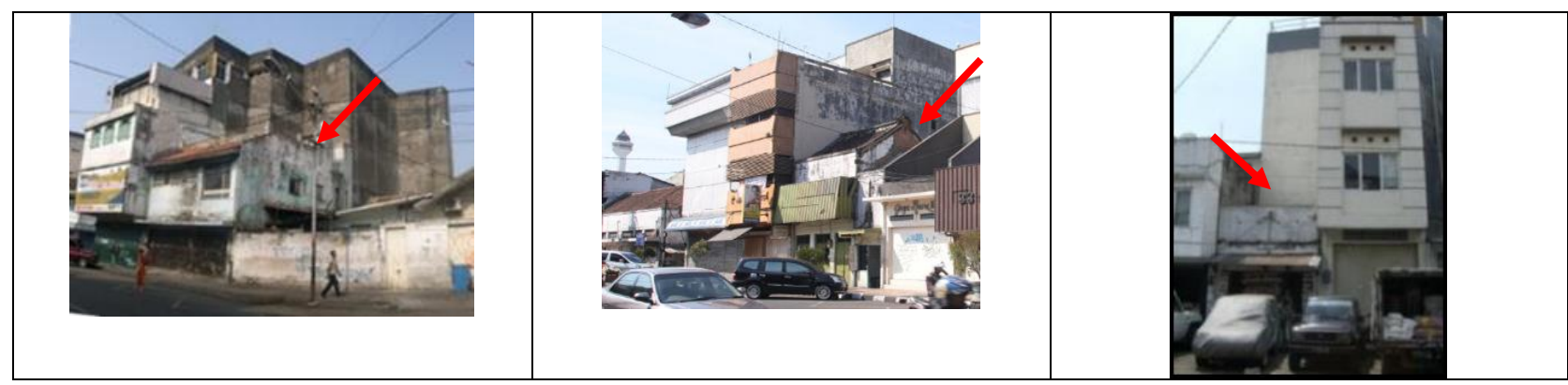

Gambar12: Beberapa contoh kasus

Sumber: survey, 2012

Gejala lain yang terlihat adalah dominasi dari bentuk-bentuk rumah-toko yang memanjang ke belakang, ke arah blok dalam. Hal ini dilihat sebagai keberhasilan pemilik toko menguasai tanah di blok dalam yang semula milik pribumi Sunda. Meningkatnya harga lahan di kawasan pusat kota mendorong para pribumi untuk menjual lahannya. Hal ini merupakan peluang terbaik bagi para pemilik toko di sisi blok sehingga rumah-toko dapat diperluas ke arah belakang meskipun status tanah informal atau tidak terdaftar.

Tipe perluasan ini adalah yang paling menguntungkan karena fungsi rumah-toko dapat dipertahankan. Pencapaian ke tempat bekerja dan pengawasan menjadi mudah karena dua kegiatan, berdagang dan berhuni dalam satu lokasi. Tipe transformasi ini terlihat dari bentuk bangunan yang pipih memanjang kebelakang ataupun penggabungan bentuk yang menghasilkan bangunan rumah-toko yang berukuran raksasa dibandingkan dengan rumah-toko di sekitarnya (Soewarno, 2020) (gambar 13).
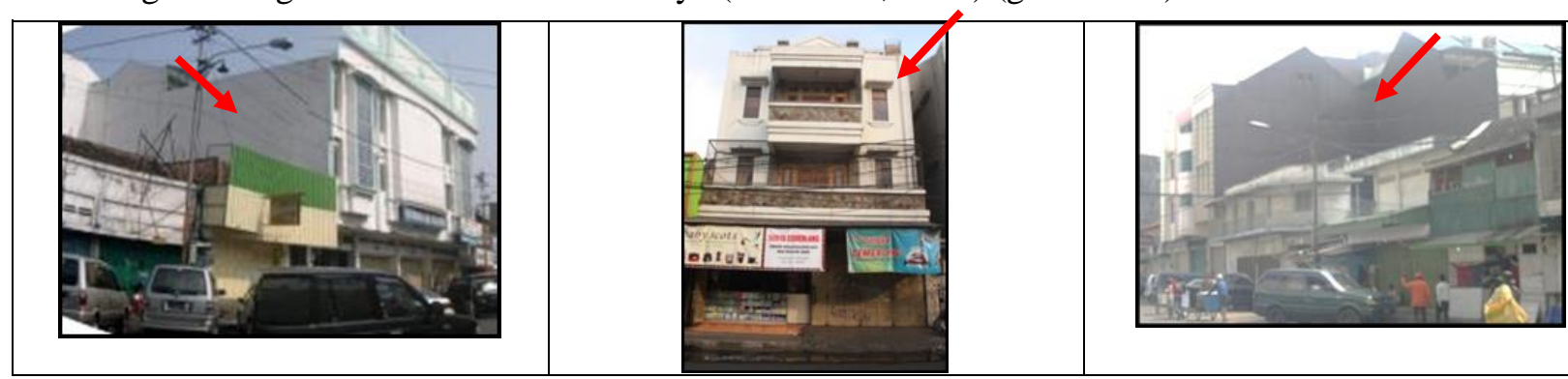

Gambar 13: Dimensi rumah-toko yang berukuran 'raksasa'

Sumber: survey, 2012

Melihat kondisi kawasan perdagangan saat ini, rumah-toko modern berlantai tingkat mendominasi kawasan. Selain itu terlihat pula tipe baru rumah-toko baik tunggal maupun kompleks ruko yang tidak mencerminakan fungsi hunian di dalamnya. Melihat transformasi yang terjadi maka dapat dikatakan bahwa transformasi didorong oleh perkembangan dimensi kapling tanahnya sehingga arah perkembangan bangunan mengikuti arah perluasan kaplingnya dan umumnya kapling dibangun 100\% sehingga bangunan identik dengan bentuk kapling. Transformasi yang terjadi tidak melihat pola dan bentuk lama tatanan massa bangunan di blok dalam (Indira Rukmi, Wara; Muthmainah, Nyimas Atika Marwiyah; Maulidi, 2019), kampung hilang dan tidak ada perbedaan bangunan di sisi dan dalam blok. 
Adapun pola tergesernya fungsi hunian sejalan pula dengan perkembangan dimensi kaplingnya sehingga dapat digambarkan seperti yang terlihat pada tabel 3.

Tabel 3: Pola tergesernya fungsi hunian

\begin{tabular}{|c|c|c|c|}
\hline \multirow{2}{*}{ Pola awal } & \multicolumn{3}{|c|}{ Pola tergesernya fungsi hunian } \\
\hline & Kapling Tetap & Kapling bertambah & Keterangan \\
\hline & & & fungsi hunian \\
\hline & & & $\begin{array}{l}\text { Hanya sedikit ditemukan } \\
\text { kasus rumah-toko dengan } \\
\text { penambahan kapling tapi } \\
\text { tidak menambah lantai. } \\
\text { Pada umumnya } \\
\text { penambahan kapling } \\
\text { akan dilanjutkan dengan } \\
\text { menambah lantai. }\end{array}$ \\
\hline \multicolumn{4}{|c|}{ Rumah-toko satu lantai } \\
\hline Toko & & & $\begin{array}{l}\text { Kasus yang paling } \\
\text { banyak terjadi, perluasan } \\
\text { ke blok dalam yang } \\
\text { diikuti dengan } \\
\text { penambahan lantai. } \\
\text { Pola lama kawasan pusat } \\
\text { kota, perdagangan di sisi } \\
\text { jalan utama dan hunian } \\
\text { di blok dalam tidak } \\
\text { berubah. } \\
\text { Transformasi terjadi di } \\
\text { blok dalam, bangunan } \\
\text { kampung menjadi } \\
\text { perpanjangan dari } \\
\text { rumah-toko. }\end{array}$ \\
\hline & & & \\
\hline
\end{tabular}

Sumber: analisis, 2013

\section{Kesimpulan}

Rumah-toko di kawasan perdagangan Pasar Baru sebagai bangunan yang menampung aktivitas berdagang telah mengalami beberapa kali perubahan. Perubahan dipicu oleh berbagai faktor baik external maupun internal. Faktor external adalah hal yang tidak dapat dihindari karena terkait aturan yang diterapkan oleh Pemerintah Daerah Kota Bandung, seperti pelebaran jalan, ketinggian bangunan. Berbeda halnya dengan faktor internal yang dikendalikan oleh pemilik rumah-toko yang dipengaruhi oleh tradisi dan ekonomi.

Tradisi dalam hal ini berkaitan dengan pembagian warisan dan usaha berdagang yang tercermin pada pembagian bangunan secara melintang sehigga setiap unit masih mempunyai akses ke jalan muka untuk kemudahan perdagangan. Keberhasilan usahan terlihat dari perkembangan bangunannya sehingga bangunan berkembang ke arah horizontal maupun vertikal. Perkembangan ini dipicu dengan meningkatnya kebutuhan ruang untuk berdagang dan terbatasnya ruang sehingga diperlukan upaya untuk memenuhi kebutuhan tersebut. 
Dengan mempelajari sejarah kawasan Pasar Baru dan mempelajari perkembangan kawasan dan berdasarkan analisis, maka dapat dikatakan bahwa transformasi bangunan mengikuti arah perluasan kapling tanahnya, baik pada rumah-toko pada kapling kecil maupun pada kapling besar sehingga terbentuk bangunan rumah-toko yang tidak beraturan. Ketidak beraturan ini dikarenakan pembangunan terjadi secara parsial, bertahap dan dalam kurun waktu tertentu (tidak sekali pembangunan).

Dominasi fungsi perdagangan mengalahkan fungsi hunian sehingga pada transformasi yang tidak diikuti dengan perkembangan kapling ke arah blok dalam fungsi hunian hilang dan bangunan digunakan hanya untuk perdagangan saja. Dominasi tipe ini menjadikan kawasan perdagangan terlihat sepi dan gelap di malam hari. Sedangkan pada transformasi dengan perluasan kapling ke arah blok dalam, fungsi hunian masih dipertahankan dengan lokasi di bagian belakang, di lokasi blok dalam (ex kampung kota). Kampung di blok dalam hanya sebagian kecil tersisa dan terletak di antara dinding-dinding tinggi yang merupakan perluasan dari bangunan rumah-toko. Hunian di blok dalam masih tetap terjaga tetapi bangunan dan pemiliknya telah berganti. Meskipun blok dalam masih berupa zona hunian tetapi suasana layaknya sebuah lingkungan hunian sudah tidak terasa.

\section{Referensi}

Alexander, C. (1987). A New Theory of Urban Design. New York: Oxford University Press.

Anthony, A. (1992). Poetics of Architecture: Theory of Design. New York: John Wiley \& Sons.

Indira Rukmi, Wara; Muthmainah, Nyimas Atika Marwiyah; Maulidi, C. (2019). Conservation of Traditional Settlement Pattern in 3_4 Ulu Sub District Palembang City. DIMENSI (Journal of Architecture and Built Environment), 46. Retrieved from http://dimensi.petra.ac.id/index.php/ars/article/view/21828

Ismet Belgawan, H. (2001). Pasar Tanah Perkotaan Informal, Suatu Sketsa Pertanahan di Pinggiran Kota Metropolitas. Retrieved from http://www.urdi.org.

Kohl, D. G. (1984). Chinese Architecture in the Straits Settlements and Western Malaya: Temples, Kongsis and HousesNo Title (First Edit). Kuala Lumpur: Heinemann Asia.

Kunto, H. (1984). Wajah Bandoeng Tempo Doeloe (I). Bandung: PT Granesia.

Mandasari, Fenny; Nurini, N. (2013). ANALISIS KARAKTER KAMPUNG PECINAN DI KAWASAN PERDAGANGAN DAN JASA PEUNAYONG PUSAT KOTA BANDA ACEH. Ruang, Jurnal Perencanaan Wilayah Kota, Undip Semarang, 1(1). Retrieved from https://ejournal3.undip.ac.id/index.php/ruang/article/view/2811

Moneo, R. (1978). Oppositions, A Journal for Ideas and Criticism in Architecture. The MIT Press, Cambridge, Massachusetts, and London, England.

Rossi, A. (1982). The Architecture of the City, Opposition Books. London: The MIT Press, Cambridge, Massachusetts, and London, England.

Santi, S. (2011). Karakteristik Rumah Toko (Ruko) Kawasan Pecinan Kota Lama di Kota Kendari. Unity, Jurnal Arsitektur, 2(1), 40-47. Retrieved from http://ojs.uho.ac.id/index.php/unity/issue/view/101

Siregar, S. (1990). Bandung The Architecture of a City in Development, Urban analysis of a regional capital a contribution to the present debate on Indonesian Urbanity and Architectural Identity, Volume I \& II. Katholieke Universiteit Leuven Belgie.

Soewarno, N.-. (2013). Kawasan Pusat Kota Sebagai Lingkungan Hunian: Transformasi Arsitektur Hunian Di Kawasan Pusat Kota Kasus: Kawasan Pasar Baru-Bandung. Parahyangan Katolik University.

Soewarno, N.-, Hidjaz, T., \& Virdianti, E. (2018). Building Transformation in Bandung City Centre: Expansion of Land Lot at Pasar Baru Area. (September), 1015-1025. https://doi.org/10.4995/isuf2017.2017.6174

Soewarno, N. (2014). Transformations of Vernacular Buildings : Chinatown in Bandung City, Indonesia. ISVS E-Journal, 3(1), 42-49.

Soewarno, N. (2020). Transformation of lots dimension to sustain the pattern of blocks at the city centre of Bandung. IOP Conference Series: Earth and Environmental Science 409 (1), 012041 Vol. , 2020, 409. Retrieved from https://iopscience.iop.org/article/10.1088/1755-1315/409/1/012041

Sudarwani, M. (2010). KARAKTER VISUAL KAWASAN PECINAN SEMARANG. Jurnal Universitas Pandanaran Semarang, 8(18). Retrieved from http://jurnal.unpand.ac.id/index.php/ dinsain/article/view/62

Sugiri, K. (2012). JEJAK KOMUNITAS TIONGHOA DAN PERKEMBANGAN KOTA BANDUNG. Jurnal Sosioteknologi Institut Teknologi Bandung, 11(26). Retrieved from http://journals.itb.ac.id/index.php/ sostek/article/view/1095

Tjiook, W. (2018). Pecinan as an inspiration The contribution of Chinese Indonesian architecture to an urban 
Budaya, 18(2). Retrieved from http://wacana.ui.ac.id/index.php/wjhi/article/view/596/pdf_37 